

Lester Thurow

Lester Thurow will present the Plenary Address, "Maintaining Technological Leadership in a World Economy" at 6:00 p.m., Monday, November 28, 1988, at the Fall MRS Meeting in Boston. With the rapid increase in technology and the equally rapid spread of new technology to industrialized countries, technological leadership is becoming increasingly important for economic survival. Thurow will cover the factors that will determine technical leadership in this world economy for the next few decades.

Thurow, a thoughtful, articulate econo-

\title{
Lester Thurow to Discuss Technological Leadership in a World Economy
}

\author{
1988 MRS Fall Meeting Plenary Address
}

mist, has greatly enhanced the discussion and study of public affairs. He is the author, co-author or editor of twelve books, including the influential The Zero Sum Society (1980). In this book, Thurow posits an economy of limits in which gains achieved by one group must be traded off against losses for others. He argues that when government bestows any benefit on a particular social class or interest group another group must give up an equivalent share of the economic pie. All efforts to redistribute the fixed shares are therefore resisted by powerful interest groups, each of which repudiates any suggestion that it surrender a portion of its share. As a result, policymaking is paralyzed.

In his next book, Dangerous Currents: $A$ State of Economics (1983), Thurow focused his critical insights on his own profession. He takes his colleagues to task for their hesitancy in accepting new concepts and paradigms when old ones have been exhausted. He accuses them of clinging to theoretical consistency and rigor while neglecting the realities of the modern world.

Lester Thurow is one of America's foremost economic educators. A member of the faculty of the Massachusetts Institute of Technology since 1968, he is currently the Gordon Y. Billard Professor of Economics in Management at MTT's Sloan School of Management, and Dean of the Sloan School of Management. In addition to his formal academic appointments, he carries on his educational activities as an articulate spokesman clarifying and illuminating the discipline of economics for the lay public and providing informed commentary on public policy issues and the state of the economics profession. He was contributing editor of Newsweek from 1981 to 1984 , during which he published a regular column. He currently writes a column for Technology Review and frequently writes for the New York Times, where he was a member of the editorial board from August to December of 1979.

Thurow received his $B A$ in political economy from William College in 1960, his MA in philosophy, politics and economics from Oxford University in 1962, and his PhD in economics from Harvard University in 1964. He taught at Harvard in 1964 and 1965 following a term as staff member on President Lyndon B. Johnson's council of economic advisers. Thurow is a member of the American Economics Association and received Harvard's David P. Wells Prize in 1968.

\section{Election Results MRS Officers and Councillors}

First Vice President and President-Elect Russell R. Chianelli (1989)

Leader, Catalytic Materials Group

Exxon Research \& Engineering Company

Second Vice President

James B. Roberto (1989)

Head, Particle-Solid Interactions Section

Oak Ridge National Laboratory

Secretary

Julia M. Phillips (1989 and 1990)

Technical Staff. Interface Physics

Research Department
Treasurer

Susan M. Kelso (1989 and 1990)

Research Staff, Electronic

Materials Laboratory

Xerox Palo Alto Research Center

Councillors (1989 through 1991)

Slade Cargill

Senior Manager, Structure of Materials,

Physical Sciences Department

IBM T.J. Watson Research Center

Elton N. Kaufmann

Associate Leader, Materials Division

Lawrence Livermore National Laboratory
Gordon E. Pike

Supervisor, Electronic Properties

of Materials Division

Sandia National Laboratories

Kathleen C. Taylor

Head, Physical Chemistry Department

General Motors Research Laboratories

We warmly congratulate the victors in the 1988 MRS elections and wish them well as they take up their new, or renewed, responsibilities in 1989. All have great experience and knowledge of the Materials Research Society, and we can look ahead with confidence to their strong and enthusiastic leadership of the Society. 